\title{
A STUDY ON TEACHING COIMPETENCE OF PRIMARY STUDENT TEACHERS WITH INTERACTIVE WHITEBOARD TECHNOLOGY
}

KEY WORDS: Interactive white board, primary studentteacher, and teaching competence.

\section{Palanisamy*}

\section{Dr.G.Sivakumar}

Ph.D Research scholar, College of Education Alagappa University Karaikudi. *Corresponding Author

Assistant Professor in Education, College of Education Alagappa University, Karaikudi.

E $\quad$ The main objective of this study is to find out the significant difference of primary student teachers (Diploma in 0 Elementary Education) in teaching competence towards the interactive whiteboard (i.e., Smart Board) concerning the locality. The survey method was used in the present study. The teaching competence scale developed and validated by the researcher has been used for collecting the data. The findings of the study were a significant difference between the rural and urban primary student teachers in their teaching competence whereas there is no difference between arts and science group student students.

\section{INTRODUCTION}

In contemporary times, the world is emerging as a global village. Innovations and novel practices attempted in different spheres of life, in progressive and developed countries are having a direct impact on the national progress and growth of developed nations, in a variety of ways. Further, the progress and growth of a country are essentially linked with literacy and quality of education. The quality of education again is dependent on the teacher preparation and the curriculum prescribed for it. The curriculum must include social realities, issues, progressive and innovative developmental processes addressing concerns that shape the future of the nation. These processes evolve and revolve around a teacher and a learner. To address these concerns and to keep pace with the times, teacher and a learner.

The demands on teachers are continuously changing and increasing. Their roles too are changing significantly. Teacher training programs must develop dedicated teachers with adequate knowledge and skills who become instrumental in the reconstruction of society. The teacher education program has thus a pivotal role to develop such prospective teachers who are prepared to learn new techniques and strategies and ready to face the challenges of the ever-changing future.

The interactive board is another piece of technology that enriches student-teacher learning with the competence necessary to adapt to a highly technological society. This specific device can be used in the classroom as a gateway to new technologies and its enhancement to one learning of teacher education. An Interactive board is a learning environment that contains all course materials of teacher education. The conception of the smart classroom has made it possible for students to tackle the features of the internet to create a meaningful and constructivist learning environment of teacher education.

Interactive board increases the flexibility of delivering subject content so that student-teacher can access knowledge and enhance their teaching competence anytime and anywhere easily. At the same time, the student-teacher gets knowledge or skills from some programs and assignments in the concept of the learning situation. An interactive board was considered as one of the essential ways to transform traditional teaching to technology-aided teaching. In the last two decades, information technology has brought a great revolution in the teacher education department. Information technology provides additional opportunities to the student-teacher for an attractive teaching-learning process.

Today the interactive board is being utilized as a new educational tool for the teacher educator and student-teacher for developing teaching competence. This technology attempts to provide the delivery of teaching-learning from teacher educators to primary student teachers in a highly flexible and comfortable way. This technology environment is one of such broad technology that has been evolved to rapidly deliver rede in classrooms. This Board is used to enhance ones learning and encourage interactive participation from primary student teachers.

\section{Need and significance of the study}

The progress of a nation depends upon the quality of teacher education. Their position and role in society are special because they give the lead by setting up standards and help to build desirable attitudes and shape the behaviors and characters among the future citizens of the country. So, it is essential to prepare primary student teachers who, in turn, will be able to motivate their students to serve the diverse needs of our nation. Teaching is a demanding and complex profession. Innumerable dedicated, talented teachers teach in schools, colleges, and universities aiming at becoming caring, competent, and effective teachers that every student expects.

In many ways, the teaching profession can be even more challenging than other Professions like engineering, medical, etc., Meeting the demands of the teaching profession requires incredible will, ability, attitude, competence, continuous learning, and proficiency in techno-pedagogical skills. The use of technological products, that is Interactive boards as teaching aids may increase the quality and success rate of teaching competence. From the above facts, it is clear that the teaching profession completed is not only based on studentteacher academic performance but also his/her teaching competence. Hence, the researcher felt the need for a study of the teaching competence of the student-teacher.

\section{Objective}

To find out the teaching competence of primary student teacher in relation to interactive white board with reference to - Gender

- The locality of primary student teacher

- The locality of the institute.

\section{Hypotheses}

There is a significant difference between male and female primary student teachers teaching competence concerning interactive whiteboard technology.

There is a significant difference between the rural and urban locality of primary student teachers' teaching competence concerning interactive whiteboard technology. 
There is a significant difference between rural and urban locality institutions of primary student teachers' teaching competence concerning interactive whiteboard technology.

\section{Methodology}

Design

A questionnaire survey was conducted to collect data and information from primary student teachers.

\section{Sample}

The sample consisted of 760 primary student teachers from teacher training institutes of Nagapattinam, Thiruvarur, Thanjavur, and Pudukkottai districts of Tamil Nadu state, India.

\section{Tools}

Teaching Competence Scale (TCS) based on Interactive whiteboard. In the present study, the reliability of the Teaching Competence Scale was established by applying the Split-Half Method. This method shows the inter-correlation of the items in the test and the correlation of the items as a whole. Samples of 42 primary student teachers were selected for the administration of the Teaching Competence Scale. The reliability co-efficient of the assessment Scale was computed to be 0.83 .

\section{StatisticalTechniques}

The arithmetic means, Standard Deviation and 't' test.

\section{Findings and Discussions}

A significant difference is found between male and female primary student teachers in the dimensions of TLM with ICT competence. Female student teachers are better than male students. This may be due to the fact of female students have more dedicated to using the TLM in the classroom and participate in more activities particularly primary education in the internship period.

The t-test results reveal that there is no significant difference between the rural and urban locality primary student teachers in their technology-based teaching competence, techno-pedagogical competence, TLM with ICT competence, technology-based evaluative competence, and life skilloriented competence.

A significant difference was found between the rural and urban institute primary student teachers in the dimensions of technology-based teaching competence, technopedagogical competence, TLM with ICT competence. The rural teacher training institute student is better than the urban teacher training students. This may be because the rural institute student teachers are getting proper guidance about teaching competence from their teacher educators.

\section{CONCLUSIONS}

It is fact that interactive whiteboards are playing a vital role in enhancing the teaching competence of student-teacher of education platforms. The interactive whiteboard is designed to help primary student teachers' competence with new challenges and developing teaching competency and performance. It provides an improved way of education in which primary student teachers teach and learn in institutes, colleges or universities with advanced and significant use of technology.

\section{REFERENCES}

1. Kothari,C.R., \& Gaurav Garg. (2014). Research methodology: Methods and techniques (3rd ed., pp.129-135) New age international (P) Limited, Publishers, New Delhi.

2. Lokesh Koul. (2008). Methodology of educational research (3rd revised ed., pp.111-125) Vikas Publishing house (P) Limited, Noida(UP).

3. Palanisamy. C \& Sivakumar. G,( 2020) "Effectiveness of Science Teaching through Smartboard Technology among Primary Teacher Training Students of Nagapattinam District."

4. IOSR Journal of Engineering (IOSRJEN), 10(2), pp.34-37.

5. Radha Mohan. (2010) Research methods in education (2nd ed., pp.35-44) Neelkamal Publications (P) Limited, Hyderabad.

6. Sivakumar. R \& Dr. A. Edward William Benjamin, (2016), Interrelationship among teaching competency and professional development of teacher educators in B.Ed. Colleges, International Education and Research Journal, Vol.2(1).

7. Sivakumar, G \& Palanisamy, C.(2018) Improvement of learning outcomes through smart virtual classroom among High school students, Paripex Indian journal of research Volume-7 Issue-10, October-2018. 